\title{
The effects of outdoor air pollution on the respiratory health of Canadian children: A systematic review of epidemiological studies
}

\author{
Laura A Rodriguez-Villamizar MD MSc ${ }^{1,2}$, Adam Magico BSc PhD ${ }^{3}$, Alvaro Osornio-Vargas MD PhD³, Brian H Rowe MD MSc $c^{1,4}$
}

LA Rodriguez-Villamizar, A Magico, A Osornio-Vargas, BH Rowe. The effects of outdoor air pollution on the respiratory health of Canadian children: A systematic review of epidemiological studies. Can Respir J 2015;22(5):282-292.

BACKGROUND: Outdoor air pollution is a global problem with serious effects on human health, and children are considered to be highly susceptible to the effects of air pollution.

OBJECTIVE: To conduct a comprehensive and updated systematic review of the literature reporting the effects of outdoor air pollution on the respiratory health of children in Canada.

METHODS: Searches of four electronic databases between January 2004 and November 2014 were conducted to identify epidemiological studies evaluating the effect of exposure to outdoor air pollutants on respiratory symptoms, lung function measurements and the use of health services due to respiratory conditions in Canadian children. The selection process and quality assessment, using the Newcastle-Ottawa Scale, were conducted independently by two reviewers.

RESULTS: Twenty-seven studies that were heterogeneous with regard to study design, population, respiratory outcome and air pollution exposure were identified. Overall, the included studies reported adverse effects of outdoor air pollution at concentrations that were below Canadian and United States standards. Heterogeneous effects of air pollutants were reported according to city, sex, socioeconomic status and seasonality. The present review also describes trends in research related to the effect of air pollution on Canadian children over the past 25 years.

CONCLUSION: The present study reconfirms the adverse effects of outdoor air pollution on the respiratory health of children in Canada. It will help researchers, clinicians and environmental health authorities identify the available evidence of the adverse effect of outdoor air pollution, research gaps and the limitations for further research.

Key Words: Air pollution; Asthma; Children; Health effects; Respiratory tract diseases

Out utdoor air pollution is a global problem with serious effects on human health (1). In fact, it has been estimated that in 2011, approximately $80 \%$ of the world's population was exposed to air pollution levels that exceeded WHO guidelines $(2,3)$. Air pollution is a complex mixture of compounds that vary greatly depending on the emission sources. Typically, the so-called criteria air pollutants (CAP, which include particulate matter $[\mathrm{PM}]$, ozone $\left[\mathrm{O}_{3}\right]$, lead $[\mathrm{Pb}]$, carbon monoxide [CO], sulphur oxides [SOx] and nitrogen oxides [NOx]), are monitored in surveillance air-quality networks. Interestingly, PM itself represents a complex mixture of particles of various sizes and concentrations of soil, metals, organics, inorganics, elemental carbon, ions and endotoxins, among other contaminants (4). Recently, the $\mathrm{PM}_{2.5}$ (PM size $\leq 2.5 \mu \mathrm{m}$ in aerodynamic diameter) has been the focus of most outdoor air pollution and health studies due to its ability to penetrate the lung tissue and induce local and systemic effects (4).

Based on findings for lung and bladder cancer, the International Agency for Research on Cancer recently classified outdoor air pollution,

\author{
Les effets de la pollution de l'air atmosphérique sur \\ la santé respiratoire des enfants canadiens : une \\ analyse systématique d'études épidémiologiques
}

HISTORIQUE : La pollution de l'air atmosphérique est un problème mondial qui a de graves effets sur la santé humaine. Les enfants sont considérés comme très vulnérables aux effets de ce type de pollution.

OBJECTIF : Mener une analyse systématique complète et à jour des publications sur les effets de la pollution de l'air atmosphérique sur la santé respiratoire des enfants du Canada.

MÉTHODOLOGIE : Les chercheurs ont effectué des recherches dans quatre bases de données électroniques entre janvier 2004 et novembre 2014 pour évaluer l'effet de l'exposition aux polluants atmosphériques sur les symptômes respiratoires, les mesures de la fonction pulmonaire et l'utilisation des services de santé en raison de maladies respiratoires chez les enfants canadiens. Deux analystes ont procédé à l'analyse indépendante du processus de sélection et de l'évaluation de la qualité, au moyen de l'échelle de Newcastle-Ottawa.

RÉSULTATS : Les chercheurs ont colligé 27 études hétérogènes sur le plan de la méthodologie, de la population, des conséquences respiratoires et de l'exposition à la pollution atmosphérique. Dans l'ensemble, les études incluses portaient sur les effets indésirables de la pollution de l'air atmosphérique à des concentrations inférieures aux normes canadiennes et américaines. Les effets hétérogènes des polluants atmosphériques étaient déclarés selon la ville, le sexe, la situation socioéconomique et le caractère saisonnier du problème. La présente analyse décrit également les tendances de la recherche à l'égard de l'effet de la pollution atmosphérique sur les enfants canadiens depuis 25 ans.

CONCLUSION : La présente étude confirme de nouveau les effets indésirables de la pollution de l'air atmosphérique sur la santé respiratoire des enfants canadiens. Elle aidera les chercheurs, les cliniciens et les autorités en santé environnementale à repérer les données probantes sur les effets négatifs de la pollution de l'air atmosphérique ainsi que les lacunes et les limites de la recherche, et ce, en prévision de prochaines recherches.

as a whole, as a group 1 carcinogen (5). In addition, well-documented associations exist between outdoor air pollution and other health conditions including asthma, cardiovascular diseases, respiratory infections, adverse birth outcomes and additional cancers, such as leukemia $(1,6,7)$. Children are considered to be highly susceptible to the effects of air pollution due to the immaturity of their immune system, the potential for developmental disruption, greater amount of time spent outdoors and, therefore, higher exposure levels, and a relatively high volume of air exchange relative to body mass $(8,9)$. In fact, outdoor air pollution consistently shows an adverse effect on childhood respiratory health, especially on asthma outcomes, with a total estimated health care cost (among 34 countries, including Canada) of approximately US $\$ 1.7$ trillion in $2010(10,11)$.

Asthma is one of the top 10 causes of years lost due to disability in male children worldwide (12). The effects of outdoor air pollution on asthma and other respiratory conditions have been the subject of study involving many adult and children populations in Canada and

${ }^{1}$ School of Public Health, University of Alberta, Edmonton, Alberta; ${ }^{2}$ Department of Public Health, School of Medicine, Universidad Industrial de

Santander, Bucaramanga, Colombia; ${ }^{3}$ Department of Pediatrics; ${ }^{4}$ Department of Emergency Medicine, University of Alberta, Edmonton, Alberta

Correspondence: Dr Laura A Rodriguez-Villamizar, Department of Emergency Medicine, University of Alberta, 7.40 University Terrace, 8440-112

Street Northwest, Edmonton, Alberta T6G 2T4. Telephone 780-492-5489, fax 780-407-3982, e-mail lrodrigu@ualberta.ca 
elsewhere. Air pollution levels in Canada are relatively low and most Canadian cities experience extreme low temperatures. Thus, Canadian studies offer a unique opportunity to examine the effects of more moderate doses of air pollution compared with those experienced in many other nations (13). In addition, Canada boasts one of the highest percentage of foreign-born citizens (14), being a society of mixed languages, cultures and genetic diversity. Recent findings suggest that the influence of genetic diversity on the population's susceptibility to air pollution is an important factor that should be considered in this field (15). In 2007, a systematic review of air pollution and children's health in Canada analyzed the results of epidemiological studies published between January 1989 and December 2004 (16). From 11 studies over a 15 -year period, the review identified associations between respiratory health effects and at least some CAP measurements. These associations were, however, often weaker than those reported in studies conducted in other countries. This was believed to be due to the lower levels of air pollution in Canada, the lower number of hours spent outdoors during the colder Canadian winters, as well as reduced levels of outdoor air pollution infiltrating into homes, which could act to reduce personal exposure to outdoor air pollution.

The objective of the present study was to conduct a comprehensive systematic review of the literature reporting the effects of outdoor air pollution on the respiratory health of children in Canada. We focused on the literature published during the past 10 years to update the previous review, identify new findings on types of associations between air pollutants and childhood respiratory health, and evaluate differences in those associations across Canadian cities.

\section{METHODS}

An a priori systematic literature review protocol was developed. The research question addressed in the present review was: what is the effect of outdoor air pollution exposure on respiratory conditions in Canadian children? Respiratory conditions included respiratory symptoms, lung function measurements and the use of health services due to respiratory disease.

\section{Search strategy}

To increase sensitivity, the search strategy used in the previous review (16) was modified. Specifically, four electronic bibliographic databases (MEDLINE, CINAHL, Scopus and CAB abstracts) were searched (Appendix 1). In general, databases were searched with a combination of terms and derived key words including variation to the following basic terms: "air pollution", "outdoor air pollution", "asthma”, "respiration disorders", "respiratory health", "respiratory symptoms", "child", "adolesc", "youth" and "Canada". In the MEDLINE search, the names of 16 specific Canadian cities were included to increase search sensitivity. The search strategy was not restricted by language or publication type. A Google Scholar web search was conducted and references of relevant studies were scanned and selected as a complementary search strategy.

\section{Study selection and data extraction}

The criteria for selecting studies included: any observational analytic design; publication date between January 1, 2004 and November 30, 2014; population included and reported data for children up to 18 years of age residing in Canada; exposure(s) included any nonbiological outdoor air pollutant whether measured directly or inferred (ie, by proximity to roadways), with special interest in the CAP $\left(\mathrm{CO}, \mathrm{NO}_{2}\right.$, $\mathrm{SO}_{2}, \mathrm{O}_{3}$, and $\mathrm{PM}_{10}$ and $\mathrm{PM}_{2.5}$ ); and outcomes included health services use (HSU), lung function measurement or self-reported respiratory symptoms. Studies that included a subset or cohort of Canadian children in which the data for the Canadians were not presented separately were excluded. Two reviewers (LR-V and AM) independently screened the identified articles' titles and abstracts to select the articles for full review, and reviewed citations that were found to be potentially relevant for inclusion. A third reviewer $(\mathrm{AO}-\mathrm{V})$ resolved disagreement. Articles selected for full review were screened in a second round to confirm that the inclusion criteria were met. Agreement was measured using kappa $(\kappa)$ statistics. Data extraction was performed by two reviewers (LR-V and AM) and summarized in standardized tables.

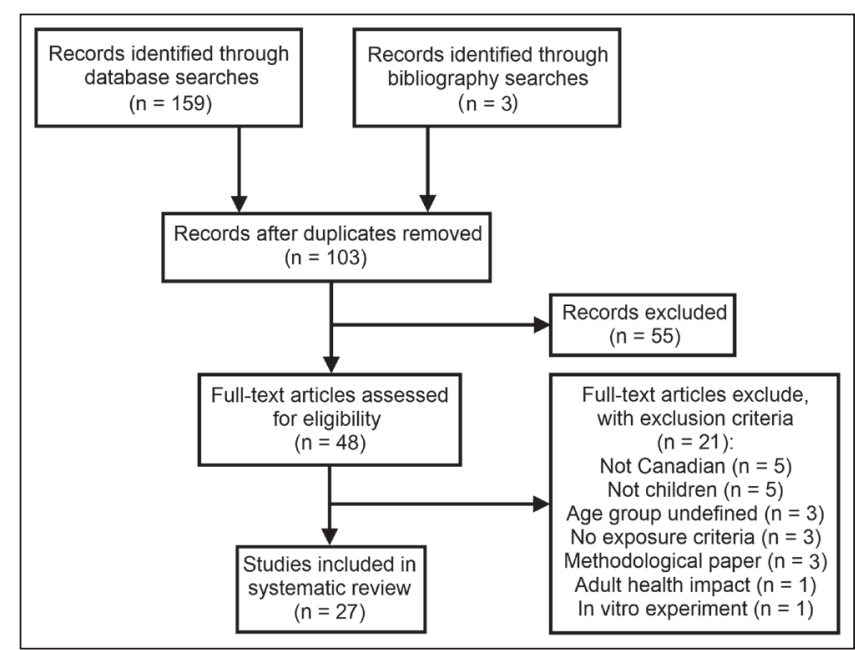

Figure 1) PRISMA flow diagram for selection of studies

\section{Quality assessment}

Study quality was assessed using the Newcastle-Ottawa Scale (NOS), which uses an eight-item rating system to evaluate the method of selection of participants, the exposure/outcome assessment, and comparability among study groups (17). Comparability was evaluated by controlling for potential confounders in terms of study design and the type of health effects under evaluation. The Cochrane NonRandomized Studies Methods Working Group recommends the use of the NOS, although the study of its psychometric properties remains in progress (18). The NOS quality scores range from 0 to $9(0$ to $4=$ poor quality; 5 to $7=$ moderate quality; 8 to $9=$ high quality). The NOS has specific formats for cohort and case-control studies only. The cohort study form was used to evaluate noncohort longitudinal studies and the case control form to evaluate case-crossover and cross-sectional studies. Two reviewers (LR-V and AM) independently performed the quality assessment of the included studies and disagreements were discussed and resolved by consensus.

\section{Data analysis}

Descriptive results of the included studies are provided. While quantitative analyses using pooled measures and random effect models were planned, they could not be conducted due to heterogeneity among study populations (children's age), outcomes and study designs. Kappa statistics and 95\% CIs were generated using Stata version 11.1 (StataCorp, USA).

\section{Search results}

\section{RESULTS}

The present review follows the PRISMA recommendations (19). As indicated in Figure 1, the systematic search identified 162 studies. After removing duplicates, initial screening with inclusion/exclusion criteria and full-text review, 27 studies were included. Studies were excluded for a variety of reasons, primarily because they did not report results on Canadian children. Reviewer agreement was substantial for identifying potentially relevant studies (disagreement $22 \%$; $\kappa=0.73$ [ $95 \%$ CI 0.70 to 0.75$]$ ) and excellent for identifying included/excluded studies in full-text review ( $\kappa=0.91$ [95\% CI 0.78 to 1.00$]$ ).

\section{Study characteristics}

The 27 studies that met the selection criteria varied in design, study location, number and type of air pollutants considered, age of children population and respiratory outcome. Tables 1 and 2 summarize the main characteristics and results of the individual studies grouped according to respiratory outcome examined (20-46).

Fifteen of the 27 studies included data from Ontario $(20,21,24,26,27,29,31,32,35-39,42,44)$, five used British Columbia (BC) data $(22,23,30,34,46)$, four used Quebec data $(28,33,40,41)$, 
TABLE 1

Characteristics and results of included studies with health services use outcomes

\begin{tabular}{|c|c|c|c|c|c|}
\hline $\begin{array}{l}\text { Reference; } \\
\text { study location; } \\
\text { and study period }\end{array}$ & $\begin{array}{l}\text { Study design; study } \\
\text { population and size }\end{array}$ & $\begin{array}{l}\text { Pollutants (mean or } \\
\text { median levels*) and } \\
\text { methods assessing } \\
\text { exposure }\end{array}$ & $\begin{array}{l}\text { Respiratory } \\
\text { outcome }\end{array}$ & Study findings & $\begin{array}{l}\text { Adjustment for } \\
\text { confounding } \\
\text { factors }\end{array}$ \\
\hline $\begin{array}{l}\text { Lin et al, } 2004(34) \text {; } \\
\text { Vancouver area; } \\
\text { 1987-1998 }\end{array}$ & $\begin{array}{l}\text { Time series study; } \\
\text { hospitalizations of } \\
6-12 \text { year olds; from } \\
\text { BC Linked Health } \\
\text { Dataset }(n=3822)\end{array}$ & $\begin{array}{l}\text { Mean } \mathrm{CO}(960), \mathrm{SO}_{2} \\
\text { (4.77), } \mathrm{NO}_{2}(18.65), \mathrm{O}_{3} \\
\text { (28.02), } \mathrm{PM}_{10} \text { (NS), } \mathrm{PM}_{2.5} \\
\text { (NS) from 1995-1998; } \\
\text { from monitoring } \\
\text { stations }\end{array}$ & $\begin{array}{l}\text { Hospitalizations } \\
\text { for asthma }\end{array}$ & $\begin{array}{l}\text { RR of asthma hospitalizations in low SES } \\
\text { group associated with: } \mathrm{NO}_{2} \text { (male, 1-day lag): } \\
1.16(95 \% \mathrm{Cl} 1.06-1.28), \mathrm{NO}_{2} \text { (male 4-day lag): } \\
1.18(95 \% \mathrm{Cl} 1.03-1.34), \mathrm{SO}_{2} \text { (female 4-day } \\
\text { lag): } 1.17(95 \% \mathrm{Cl} 1-1.37) \text {, and } \mathrm{SO}_{2} \text { (female } \\
\text { 6-day lag): } 1.19(95 \% \mathrm{Cl} 1-1.42)\end{array}$ & $\begin{array}{l}\text { Sex, temperature, } \\
\text { relative humidity, } \\
\text { SES, day of the } \\
\text { week }\end{array}$ \\
\hline $\begin{array}{l}\text { Yang et al, } \\
2004 \text { (46); } \\
\text { Greater Vancouver; } \\
\text { 1995-1999 }\end{array}$ & $\begin{array}{l}\text { Case-crossover, } \\
\text { case-control and } \\
\text { time-series analyses; } \\
\text { first hospital admis- } \\
\text { sions of 0-3 year olds, }\end{array}$ & $\begin{array}{l}\text { Mean } \mathrm{CO}(700), \mathrm{O}_{3}(14.3) \\
\mathrm{NO}_{2}(16.8), \mathrm{SO}_{2}(3.5) \\
\mathrm{PM}_{10}(13.3) \text { and } \mathrm{PM}_{2.5} \\
(7.7) ; \text { from local } \\
\text { monitors }\end{array}$ & $\begin{array}{l}\text { Hospitalizations } \\
\text { for respiratory } \\
\text { disease (includ- } \\
\text { ing asthma) }\end{array}$ & $\begin{array}{l}\text { OR of respiratory hospitalizations associated } \\
\text { with 3-day lag mean and max } \mathrm{PM}_{10-2.5} \text { : } \\
1.22(95 \% \mathrm{Cl} 1.02-1.48) \text { and } 1.14(95 \% \mathrm{Cl} \\
0.99-1.32) \text {, respectively; time-series analysis } \\
\text { gave weaker associations }\end{array}$ & $\begin{array}{l}\text { Sex, SES, day of } \\
\text { the week, season, } \\
\text { study year, sea- } \\
\text { son and influenza } \\
\text { hospitalizations }\end{array}$ \\
\hline
\end{tabular}

Lin et al, 2005 (35);

Toronto;

1998-2001

Luginaah et al, 2005 (37);

Windsor;

1995-2000 excluding birth-related

admissions $(n=1610)$

Case-crossover design; Mean $\mathrm{PM}_{10}$ (20.41), $\mathrm{PM}_{2.5}$ Hospitalization hospitalizations of

0-14 year olds $(n=6782)$

Time series and casecrossover design; hospitalizations $0-14$ year olds $(n=1602)$

Dales et al, 2006 (25); 11 of the largest Canadian cities; 1986-2000

Villeneuve et al, 2007 (45); Edmonton; 1992-2002
Time series study; 0-27 day olds $(\mathrm{n}=8586)$

Case-crossover design Sur (time stratified); ED visits of 2-14 year olds $(n=20,392)$ hospitalizations of
(9.59),

$\mathrm{PM}_{10-2.5}$ (10.86), for respiratory $\mathrm{CO}$ (1160), $\mathrm{SO}_{2}$ (4.73), $\mathrm{NO}_{2}$ (24.54), $\mathrm{O}_{3}$ (38.06); from monitoring stations

Mean $\mathrm{NO}_{2}$ (38.9), Hospitalizations $\mathrm{SO}_{2}$ (27.5), $\mathrm{CO}$ (1300), for respiratory $\mathrm{PM}_{10}$ (50.6), TRS (8), and disease coefficient of haze $(0.5)$; from monitoring stations

\section{Mean $\mathrm{NO}_{2}(21.8)$} $\mathrm{SO}_{2}$ (4.3), $\mathrm{CO}(1.0), \mathrm{O}_{3}$ (17.0), and $\mathrm{PM}_{10}(\mathrm{NS})$;

Hospitalizations for respiratory disease from monitoring stations (population weighted average)

Summer/winter

ED visits for median $\mathrm{PM}_{10}(22.0 / 19.0)$, asthma $\mathrm{PM}_{2.5}$ (7.0/7.3), CO (600/900), $\mathrm{SO}_{2}(2.0 / 3.0)$, $\mathrm{NO}_{2}(17.5 / 28.5), \mathrm{O}_{3}$ (38.0/24.3); from monitoring stations
OR of hospitalizations for 6-day average exposure to: $\mathrm{PM}_{10-2.5}$ : boys $1.15(95 \% \mathrm{Cl}$ 1.02-1.3), girls $1.18(95 \% \mathrm{Cl} 1.01-1.36)$; $\mathrm{PM}_{10}$ : boys 1.25 (95\% Cl 1.01-1.54); $\mathrm{NO}_{2}$ : girls $1.31(95 \% \mathrm{Cl} 1.05-1.63) ; \mathrm{PM}_{2.5}$, $\mathrm{O}_{3}$ and $\mathrm{SO}_{2}$ showed no associations

Time Series RR: $\mathrm{NO}_{2}$ : female 2-day lag: 1.19 (95\% Cl 1.002-1.411); $\mathrm{SO}_{2}$ : female Current-Day: 1.11 (95\% Cl 1.011-1.221); CO: female 2-day lag: 1.07 (95\% Cl 1.001-1.139); Cross-over design OR: CO: female current day, 2-day lag and 3-day lag: $1.15(95 \% \mathrm{Cl} 1.006-1.307), 1.19(95 \% \mathrm{Cl}$ $1.020-1.379)$ and 1.22 (95\% Cl 1.022-1.459)

The percentage of variation for IQR increase for all gasses combined was $9.61 \%(95 \% \mathrm{Cl}$ 4.52-14.7); individually: $\mathrm{O}_{3}: 2.67(95 \% \mathrm{Cl} 0.98$ 4.39); $\mathrm{NO}_{2} 2.48$ (95\% Cl 1.18-3.8); $\mathrm{SO}_{2}: 1.41$ (95\% Cl 0.35-2.47); CO: 1.3 (95\% Cl 0.13-2.49)

Positive association were observed in warm season and higher in 2-4 years: OR 5-day average: $\mathrm{NO}_{2} 1.50(95 \% \mathrm{Cl} 1.31-1.71)$, CO 1.48 (95\% Cl 1.27-1.72), $\mathrm{PM}_{2.5}: 1.16$ (95\% $\mathrm{Cl} 1.04-1.28)$ and $\mathrm{PM}_{10}: 1.16(95 \% \mathrm{Cl} 1.05-$ 1.28); For 5-14 years: OR 5-day average: $\mathrm{NO}_{2}$ : $1.13(95 \% \mathrm{Cl} 1.02-1.24), \mathrm{O}_{3}: 1.14(95 \% \mathrm{Cl}$ 1.05-1.24), $\mathrm{PM}_{2.5}: 1.10$ (95\% Cl 1.02-1.17), $\mathrm{PM}_{10}: 1.14$ (95\% Cl 1.06-1.22); many of the 1- and 3-day lags were also significant during the warm season for various pollutants

Mean/median CO
Szyszkowicz et al, 2008 (43); Edmonton; 1992-2002

\section{Longitudinal study; 0-10 years ED visits $(n=18,891)$}

(700/600), $\mathrm{NO}_{2}$ (21.9/19.7), $\mathrm{SO}_{2}(2.6 / 2.2)$ $\mathrm{O}_{3}(18.6 / 17.8), \mathrm{PM}_{10}$ (22.6/19.4), $\mathrm{PM}_{2.5}$ (8.5/6.2); from monitoring stations
ED visits for asthma
Many positive associations were observed in the warm season; the higher percentage increase for each pollutant was: CO (2-day lag) male: $17.7 \%(95 \% \mathrm{Cl} 10.2-25.6), \mathrm{NO}_{2}$ (2-day lag) male: $19.2 \%(95 \% \mathrm{Cl} 11.4-27.6), \mathrm{O}_{3}$ (same day) female: $17.8 \%$ (95\% Cl 7.1-29.5), $\mathrm{PM}_{10}$ (2-day lag) male: $7.4 \%(95 \% \mathrm{Cl} 3.1-11.9)$, $\mathrm{PM}_{2.5}$ (same-day) female: $7.7 \%(95 \% \mathrm{Cl} 5.2$ 10.3), $\mathrm{O}_{3}$ (1-day lag), $\mathrm{PM}_{10}$ (same-day), and $\mathrm{PM}_{2.5}$ (2-day lag) showed positive variations for some age/sex/season combinations

$\begin{array}{ccl}\text { Burra et al, } & \text { Longitudinal study; } & \text { Mean } \mathrm{SO}_{2}(9.7), \\ 2009(20) ; & \text { family physician and } & \mathrm{NO}_{2}(39.2), \mathrm{O}_{3}(33.3) \\ \text { Toronto; } & \text { specialists service } & \text { and } \mathrm{PM}_{2.5}(17.9) ; \\ 1992-2001 & \text { claim records for } & \text { from monitoring } \\ & 1-17 \text { year olds } & \text { stations } \\ & (\mathrm{n}=1,146,215) & \end{array}$
Asthma
physician visits
RR for pollutants by SES quintiles (Q1/Q5) were: $\mathrm{SO}_{2}: 1.005(95 \% \mathrm{Cl} 1.000-1.010), \mathrm{NO}_{2}$ : 1.002 (95\% Cl 0.995-1.008), and $\mathrm{PM}_{2.5}$ : 1.006 (95\% Cl 0.997-1.015); low SES groups had higher $\mathrm{RR}$ in $\mathrm{SO}_{2}$ and $\mathrm{PM}_{2.5}$ models

Sex, temperature, pollutant interactions and seasonality

Temperature, sex, humidity, barometric pressure, seasonality

Long-term temporal trends, day of week effects, weather variables, other gases and $\mathrm{PM}_{10}$

Temperature, relative humidity, season, aeroallergens, and ED visits for influenza (1)

Sex, temperature, relative humidity, day of the week
SES, temperature, barometric pressure, 24 h mean relative humidity, day of the week 
TABLE 1 - CONTINUED

Characteristics and results of included studies with health services use outcomes

\begin{tabular}{|c|c|c|c|c|c|}
\hline $\begin{array}{l}\text { Reference; } \\
\text { study location; } \\
\text { and study period }\end{array}$ & $\begin{array}{l}\text { Study design; study } \\
\text { population and size }\end{array}$ & $\begin{array}{l}\text { Pollutants (mean or } \\
\text { median levels*) and } \\
\text { methods assessing } \\
\text { exposure }\end{array}$ & $\begin{array}{l}\text { Respiratory } \\
\text { outcome }\end{array}$ & Study findings & $\begin{array}{l}\text { Adjustment for } \\
\text { confounding } \\
\text { factors }\end{array}$ \\
\hline $\begin{array}{l}\text { Smargiassi et al, } \\
2009 \text { (41); } \\
\text { Montreal (Quebec); } \\
\text { 1996-2004 }\end{array}$ & $\begin{array}{l}\text { Case-crossover } \\
\text { design (time } \\
\text { stratified); } 2-4 \text { year } \\
\text { olds living near a } \\
\text { refinery }(n=1579)\end{array}$ & $\begin{array}{l}\text { Daily peak mean } \mathrm{SO}_{2} \\
\text { (east/southwest of } \\
\text { refineries) using monitor- } \\
\text { ing stations (23.8/12.8); } \\
\text { and AERMOD dispersion } \\
\text { model }(19.2 / 16.0)\end{array}$ & $\begin{array}{l}\text { Asthma ED } \\
\text { visits or } \\
\text { hospital } \\
\text { admissions }\end{array}$ & $\begin{array}{l}\text { OR for same-day ED visits: } 1.10 \text { (95\% Cl } \\
\text { 1.00-1.22), and hospital admissions: } 1.42 \\
(95 \% \mathrm{Cl} 1.10-1.82)\end{array}$ & $\begin{array}{l}\text { Temperature, } \\
\text { relative humidity, } \\
\text { regional/ } \\
\text { background air } \\
\text { pollutant levels }\end{array}$ \\
\hline $\begin{array}{l}\text { Henderson et al, } \\
2011(30) ; \\
\text { Southeast corner } \\
\text { of BC } \\
92 \text { days: } \\
\text { July to September } \\
2003\end{array}$ & $\begin{array}{l}\text { Cohort study; } \\
\text { Residents at the } \\
\text { southeast area of BC } \\
\text { with a reliable } \\
\text { geocodable residen- } \\
\text { tial address in health } \\
\text { databases; included } \\
\text { newborns } \\
\text { (n=281,711; } 21.6 \% \\
<20 \text { years old) }\end{array}$ & $\begin{array}{l}\text { Mean } \mathrm{PM}_{10} \text { during days of } \\
\text { smoke coverage from } \\
\text { forest fires; Comparison } \\
\text { of two methods: } \\
\text { TEOM monitoring } \\
\text { stations (45.9); } \\
\text { and CALPUFF dispersion } \\
\text { model (44.2) }\end{array}$ & $\begin{array}{l}\text { Respiratory or } \\
\text { cardiovascular } \\
\text { physician visits } \\
\text { and hospital } \\
\text { admissions }\end{array}$ & $\begin{array}{l}\text { OR change due to } 10 \mu \mathrm{g} / \mathrm{m}^{3} \text { increase in } \\
\text { total } \mathrm{PM}_{10}(\mathrm{TEOM}) \text { in respiratory hospital } \\
\text { admissions: } 1.05(95 \% \mathrm{Cl} 1.00-1.10) \text {, and } \\
\text { cardiovascular admissions: } 1.00(95 \% \mathrm{Cl} \\
0.96-1.05)\end{array}$ & Age, sex, SES \\
\hline $\begin{array}{l}\text { Lavigne et al, } 2012 \\
\text { (32); Windsor } \\
\text { (Ontario); } \\
\text { 2002-2009 }\end{array}$ & $\begin{array}{l}\text { Case-crossover } \\
\text { design (time strati- } \\
\text { fied); } 2-14 \text { year olds } \\
\text { hospitalized for } \\
\text { asthma }(n=3728)\end{array}$ & $\begin{array}{l}\text { Mean summer/winter SO } \\
(2.1 / 1.7), \mathrm{NO}_{2}(9.8 / 7.4) \\
\mathrm{CO}(400 / 300), \mathrm{PM}_{2.5} \\
(7.1 / 7.4), \mathrm{O}_{3}(13.2 / 26.0) \\
\text { from monitoring stations }\end{array}$ & $\begin{array}{l}\text { Asthma ED } \\
\text { visits }\end{array}$ & $\begin{array}{l}\text { Increased risk of warm season asthma ED } \\
\text { visit of } 19 \%, 25 \% \text { and } 36 \% \text { associated with } \\
\text { increases in IQR of } 1 \text {-day lagged exposure } \\
\text { to } \mathrm{SO}_{2}, \mathrm{NO}_{2} \text { and } \mathrm{CO} \text { levels, respectively }\end{array}$ & $\begin{array}{l}\text { Daily number of } \\
\text { influenza ED } \\
\text { visits, } \\
\text { temperature and } \\
\text { relative humidity. }\end{array}$ \\
\hline $\begin{array}{l}\text { Lewin et al, } \\
2013 \text { (33); } \\
\text { Shawiningan } \\
\text { (Quebec); } \\
\text { 1999-2008 }\end{array}$ & $\begin{array}{l}\text { Case-crossover } \\
\text { design (time strati- } \\
\text { fied); hospitalized } \\
0-4 \text { year olds living } \\
\text { near aluminium } \\
\text { smelter } \\
(n=396)\end{array}$ & $\begin{array}{l}\text { Exposure calculated } \\
\text { by: } \% \text { of hours/day each } \\
\text { residence was downwind } \\
\text { of the smelter; and daily } \\
\text { mean } \mathrm{SO}_{2}(6.3) \text { and } \\
\mathrm{PM}_{2.5}(13.5) \text { from moni- } \\
\text { toring station }\end{array}$ & $\begin{array}{l}\text { Hospitalization } \\
\text { for asthma or } \\
\text { bronchiolitis }\end{array}$ & $\begin{array}{l}\text { OR of hours downwind of a smelter on } \\
\text { same-day hospitalization of } 2-4 \text {-year-old chil- } \\
\text { dren: } 1.27(95 \% \mathrm{Cl} 1.03-1.56) \text {, and } \mathrm{PM}_{2.5} \\
\text { exposure: } 1.22(95 \% \mathrm{Cl} 1.03-1.11)\end{array}$ & $\begin{array}{l}\text { Average daily wind } \\
\text { direction and } \\
\text { speed }\end{array}$ \\
\hline $\begin{array}{l}\text { To et al, } \\
2013 \text { (44); Ontario; } \\
2003-2006\end{array}$ & $\begin{array}{l}\text { Longitudinal study; } \\
\text { All Ontario residents } \\
\text { with asthma } \\
\text { registered at the } \\
\text { (OASIS) database }\end{array}$ & $\begin{array}{l}\text { Canada } \\
\text { 2003/2004/2005/2006) } \\
\text { mean AQHI } \\
(3.87 / 3.64 / 3.83 / 3.34), \\
\mathrm{NO}_{2}(\mathrm{NS}), \mathrm{O}_{3}(\mathrm{NS}), \\
\text { and } \mathrm{PM}_{2.5}(\mathrm{NS}) \\
\text { measures; from } \\
\text { monitoring stations }\end{array}$ & $\begin{array}{l}\text { Asthma-attributed } \\
\text { hospitaliza- } \\
\text { tions, ED and } \\
\text { outpatient visits }\end{array}$ & $\begin{array}{l}\text { RR for } 1 \text {-unit increase in the AQHI by same-day } \\
\text { outpatient visits: } 1.056(95 \% \mathrm{CI} 1.053-1.058) \\
\text { and hospitalization: } 1.0256(95 \% \mathrm{Cl} 1.053- \\
\text { 1.058), and 2-day lag ED visits: } 1.013(95 \% \mathrm{Cl} \\
1.010-1.017)\end{array}$ & $\begin{array}{l}\text { Age group, season, } \\
\text { residence area, } \\
\text { and year }\end{array}$ \\
\hline $\begin{array}{l}\text { Szyszkowicz et al, } \\
2014 \text { (42); } \\
\text { Windsor (Ontario); } \\
\text { 2004-2010 }\end{array}$ & $\begin{array}{l}\text { Case-crossover } \\
\text { design (time strati- } \\
\text { fied); ED visits for } \\
2-14 \text { year olds; } \\
(n=2151)\end{array}$ & $\begin{array}{l}\mathrm{AQHI} \text { for Canada; hourly } \\
\mathrm{AQHI} \text { calculations, } \mathrm{NO}_{2} \\
\mathrm{O}_{3} \text {, and } \mathrm{PM}_{2.5} \text { measures } \\
\text { from two monitoring sta- } \\
\text { tions }\end{array}$ & $\begin{array}{l}\text { Asthma ED } \\
\text { visits }\end{array}$ & $\begin{array}{l}\text { Positive and statistically significant associations } \\
\text { were observed for same-day and 9-day lag } \\
\text { exposure (both OR } 1.11 \text { [95\% Cl 1.01-1.21]) } \\
\text { and } \\
\text { 3-day lag exposure (OR } 1.09 \text { [95\% Cl 1.00- } \\
\text { 1.18]) }\end{array}$ & $\begin{array}{l}\text { Ambient tempera- } \\
\text { ture, relative } \\
\text { humidity and } \\
\text { daily counts of } \\
\text { ED visits for influ- } \\
\text { enza }\end{array}$ \\
\hline
\end{tabular}

${ }^{*}$ Parts per billion for gasses, $\mu \mathrm{g} / \mathrm{m}^{3}$ for particulate matter (PM). AQHI Air Quality Health Index; BC British Columbia; CO Carbon monoxide; ED Emergency department; IQR Interquartile range; $\mathrm{NO}_{2}$ Nitrogen dioxide; NS Not stated; $\mathrm{O}_{3}$ Ozone; OASIS Ontario Asthma Surveillance Information System; RR Relative risk; SES Socioeconomic status; $\mathrm{SO}_{2}$ Sulphur dioxide; TEOM Tapered element oscillating microbalance; TRS Total reduced sulphur

two used Alberta data $(43,45)$ and one study used data from 11 Canadian cities (25). At least one of the two Ontario cities Windsor and Hamilton - were represented in 13 of the articles analyzed. The most common study designs used were longitudinal $(n=7)$, cross-sectional $(n=7)$ and case-crossover $(n=6)$. All studies included children $<15$ years of age, except for one that included children up to 17 years of age (20). Twelve (44\%) studies received funding support from provincial or federal government agencies. Eighteen studies focused on exposures to at least one of the CAP, two used proximity to roads as the exposure source, two used Air Quality Health Index $(\mathrm{AQHI})$ as the tested exposure, and four examined CAP as well as proximity to roads or industrial facilities. One study measured exposure to total suspended particles (TSP) in Hamilton, and other polycyclic aromatic hydrocarbon (PAH) and volatile organic compounds in Montreal (Quebec). Of the 23 studies tracking CAP or TSP, the majority $(n=13)$ used fixed ambient air monitoring stations to assess exposures, two modelled exposures, seven used a combination of measurements and models, and one used personal monitoring devices. Regarding respiratory outcomes, 14 studies relied on health services use for respiratory conditions as the main health outcome (Table 1), while five used lung function measures based on spirometry; four used self-report of respiratory symptoms; three used a combination of lung function measures and symptoms; and one calculated incidence of asthma diagnosis (23) (Table 2). 


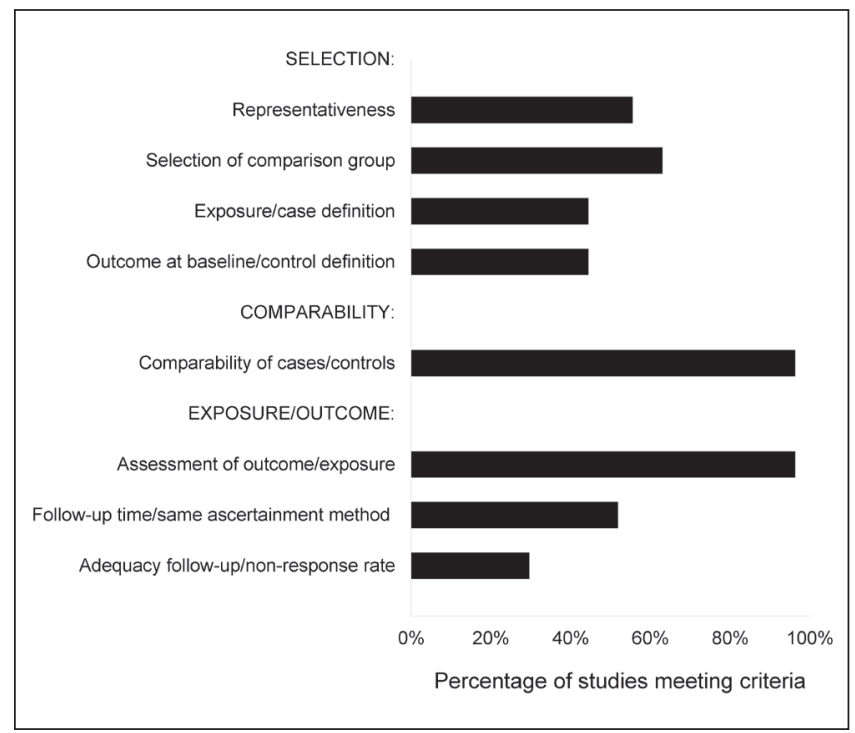

Figure 2) Quality assessment of the 27 included studies using the NewcastleOttawa Scale, which assess three main groups of criteria consisting of a total of eight items. All criteria are assessed in a binary fashion (0 or 1), except for 'comparability of cases/controls', which was scored as 0,1 or 2. Percentages indicate the total score of all the articles in the indicated categories out of the total possible score

\section{Quality assessment}

The overall methodological quality assessment of the studies was moderate, with a mean $( \pm$ SD) NOS score of $6.04 \pm 1.3$ from a maximum score of 9 . Figure 2 summarizes the methodological quality of the studies based on the NOS items. All studies clearly defined outcomes and most $(96.3 \%)$ of the studies controlled for potential confounding variables; however, the nonexposed group definition, the follow-up criteria (especially for noncohort longitudinal studies), and the report of nonparticipation (in cross-sectional studies) were not met in $>50 \%$ of the articles.

\section{HSU as a result of air pollution exposure}

Nine studies focused on HSU for the treatment of asthma symptoms. A variety of age ranges and pollutants had positive associations with asthma-related HSU (Figure 3A). Higher adverse effects were reported consistently during the warm season in different cities. The highest percentage increase of emergency department (ED) visits for asthma (up to $36 \%$ ) was reported in one-day lag exposures to $\mathrm{CO}$, $\mathrm{SO}_{2}$ and $\mathrm{NO}_{2}$ in Windsor during the warm season (32), and the highest percentage increase of asthma hospitalization (up to $42 \%$ ) was reported in children exposed to $\mathrm{SO}_{2}$ in refinery areas in Montreal (41). Studies examining $\mathrm{NO}_{2}$ produced the most consistent results, showing a positive association with HSU at different ages (from 0 to 17 years of age). There was also evidence that the effect of $\mathrm{NO}_{2}$ was exacerbated among female children of low socioeconomic status $(20,34)$. Two pollutants $\left(\mathrm{CO}, \mathrm{O}_{3}\right)$ gave conflicting results among studies; however, it is important to note that the studies generally differed according to age and city studied, as well as the study period. Two studies using the AQHI as an air pollution indicator also showed positive associations with HSU.

Five studies examined HSU for general respiratory conditions (which could include, but were not limited to, asthma) and infections. As with HSU for asthma, several positive associations were demonstrated (Figure $3 \mathrm{~B}$ ). In this case, $\mathrm{CO}, \mathrm{NO}_{2}$ and $\mathrm{PM}_{2.5-10}$ were positively associated with $\mathrm{HSU}$ for respiratory ailments. Conflicting results were demonstrated for $\mathrm{O}_{3}, \mathrm{PM}_{10}$ and $\mathrm{SO}_{2}$, depending on the city and age of the children studied.
Air pollution effects on lung function and asthma symptoms/diagnosis A variety of pollutants was tested for an association with increased asthma symptoms (AS) or decreased lung function (LF) (Figure 3C). LF was typically assessed using forced vital capacity (FVC) and/or forced expiratory volume in $1 \mathrm{~s}\left(\mathrm{FEV}_{1}\right)$ measures. The most consistent null effects were reported for $\mathrm{O}_{3}$, when either LF or AS were examined in children, in Windsor and Hamilton. Associations with reduced LF were also apparent for PAH (Montreal) and TSP (Hamilton). No associations with reduced lung function were seen with benzene (Montreal) or $\mathrm{PM}_{2.5-10}$ (Windsor); and no increased AS were apparent with increased $\mathrm{PM}_{10}$ exposure (Hamilton). While proximity to roadways had no association with AS in Hamilton, it did show an effect on LF in three Windsor-based studies $(21,26,27)$. Inconsistent results were observed for $\mathrm{NO}_{2}, \mathrm{PM}_{2.5}$ and $\mathrm{SO}_{2}$, even though the contradictory studies often examined similar health effects and age groups in the same cities. For $\mathrm{NO}_{2}$, most LF data failed to demonstrate an association (Montreal and Windsor), while one showed the opposite (Windsor), as did one study using AS (Hamilton). There was no clear pattern in the $\mathrm{PM}_{2.5}$ data, with three Windsor articles identifying effects on LF and/or inflammation, and two from Montreal and Windsor showing no effect on LF. For $\mathrm{SO}_{2}$, four studies using either LF, AS, or LF and inflammation failed to demonstrate an effect in Hamilton and Windsor, while a single study in Montreal detected an association with AS. Two studies showed effect modification of $\mathrm{NO}_{2}$ on asthma symptoms by chronic psychosocial stress and other allergic disease $(20,27)$.

Only one study examined increases in asthma diagnosis, as a consequence of exposure to CAPs, wood smoke and black carbon (soot), or industrial and road proximity in children $<5$ years of age from southwest $\mathrm{BC}$ (23). Positive associations were seen with $\mathrm{CO}, \mathrm{NO}, \mathrm{NO}_{2}, \mathrm{PM}_{10}$, $\mathrm{SO}_{2}$, black carbon and industrial proximity (Table 2).

\section{DISCUSSION}

The present systematic review summarizes the evidence available from epidemiological studies exploring the association of outdoor air pollution on Canadian children's respiratory in the past 10 years. From 2004 to 2014, 27 new studies were identified; all but one (40) reconfirm the adverse effects of outdoor air pollution on respiratory symptoms, lung function and HSU at different CAP concentrations, almost all of which were below United States and Canadian (available only for $\mathrm{PM}_{2.5}$ and $\mathrm{O}_{3}$ ) standards (47). The present review also identified that the increase in respiratory-related ED visits and hospitalizations were demonstrated in higher proportions than the outpatient visits, and that those effects are even higher in places near industrial facilities or refinery areas in Windsor and Montreal, respectively. The findings showed more consistent associations of adverse respiratory outcomes for traffic-related exposures of $\mathrm{PM}$ and $\mathrm{NO}_{2}$, especially related to health services use. Some studies also report differential effects of gases and particles on female and socially disadvantaged children.

Our review updates a similar study covering 1989 to 2004 (16), enabling us to compare publications and describe trends in the research related to the effect of air pollution on Canadian children over the past 25 years. There are differences, mainly in terms of the number of publications, type of study designs, exposure measurement and study locations. Compared with publications from 1989 to 2004, the publications in the past decade were: more than twofold more frequent, over a shorter period of time studied; conducted mainly in Windsor and Hamilton rather than in Toronto and Vancouver; most commonly used cross-sectional, longitudinal and case-crossover study designs rather than time-series analysis; and increasingly introduced air pollutant exposure assessment using model-based small area estimations (eg, landuse regression models), in addition to data from fixed ambient air monitoring stations. These changes could be explained by several factors, such as the increase in funding for the study of environmental-related health conditions in Canadian children (48), the increased access to high quality administrative data, growing societal concern for the potential health effects of industrial development around cities (12 of 27 studies between 2004 and 2014 were supported by provincial or federal 
A

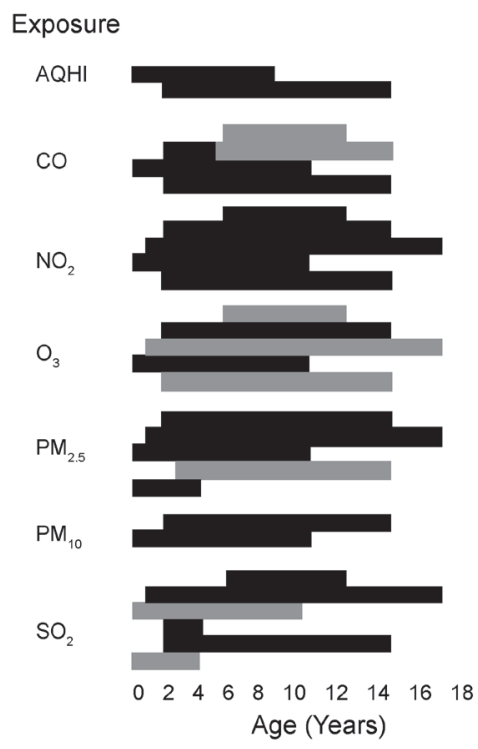

B

\section{Exposure}

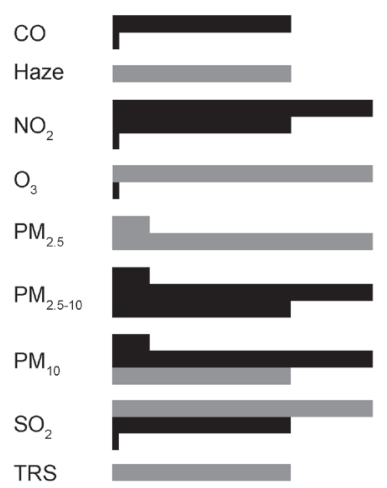

C

Ref. (study location)

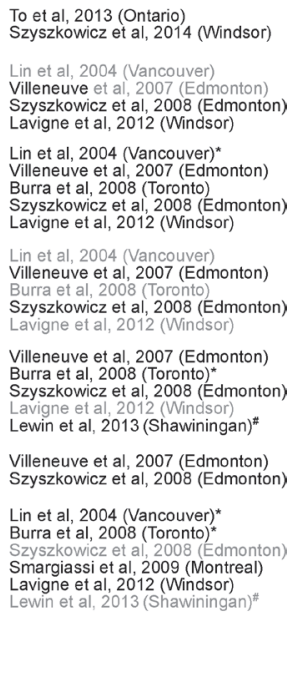

Lin et al, 2004 (Vancouver) Szyszkowicz et al, 2008 (Edmonton) Lavigne et al, 2012 (Windsor) Lin et al, 2004 (Vancouver)* $^{*}$ Villeneuve et al, 2007 (Edmonton) Szyszkowicz et al, 2008 (Edmonton)
Lavigne et al, 2012 (Windsor) Lin et al, 2004 (Vancouver) Villeneuve et al, 2007 (Edmonton) Burra et al, 2008 (Toronto)
Szyszkowicz et al, 2008 (Edmonton) Lavigne et al, 2012 (Windsor) Villeneuve et al, 2007 (Edmonton) Szyszkowicz et al, 2008 (Edmonton) Lewin et al, 2013 (Shawiningan) Villeneuve et al, 2007 (Edmonton)
Szyszkowicz et al, 2008 (Edmonton) Lin et al, 2004 (Vancouver)* Szyszkowicz et al, 2008 (Edmonton) Smargiassi et al, 2009 (Montreal) Lavigne et al, 2012 (Windsor)
Exposure

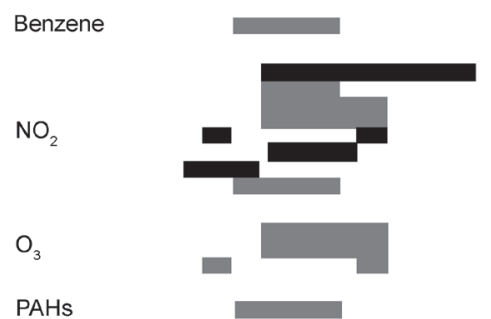

PAHs

$\mathrm{PM}_{25-10}$

$\mathrm{PM}_{2.5}$

$\mathrm{PM}_{10}$

Roads

$\mathrm{SO}_{2}$

TSP

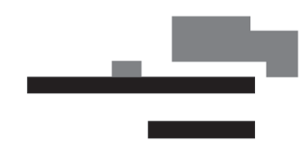

Ref. (Study Location)

Smargiassi et al, 2014 (Montreal)*

Chen et al, 2008 (Vancouvere*t*

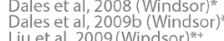

Litet at, 2009 (Windsol,
Sahsuvaroglu et al, 2009 (Hamilton)* Dell et al, 2014 (Toronto) $)^{4}$ (T) Smargiassi et al, 2014 (Montreal)**

Dales et al, 2009b (Windsor)*
Livet al. 2009 (Winds Liu et al, 2009 (Windsor)**
Sahsuvaroglu et al, 2009 (Hamilton)" Smargiassi et al, 2014 (Montreal)*

Dales et al, 2008 (Windsor)*

Dales et al, 2008 (Windsor)* Liv et al, 2009 (Windsor) (Wt $^{*+}$ Johnson tet al, 2013 (Windsor)*
Smargiassi et al, 2014 (Montreal)*

Sahsuvaroglu et al, 2009 (Hamilton)*

Dales et al, 2008 (Windsor)**
Dales et al, 2009 a (Windsor)* Sahsuraroglu et al, 2009(Hamilton)*

Dales et al, 2008 (Windsor)** Liu et al, 2009 (Windsor)*t) Sahsuvaroglu et al, 2009 (Hamilton) $)^{\sharp}$ Pouliou et al, 2008 (Hamilton)* Age (Years)

Ref. (Study Location)

Luginaah et al, 2005 (Windsor) Dales et al, 2006 (11 cities) Luginaah et al, 2005 (Windsor) Lin et al, 2005 (Toronto) Luginaah et al, 2005 (Windsor) Dales et al, 2000 (11 cities) Lin et al, 2005 (Toronto) Dales et al, 2006 (11 cities) Yang et al, 2004 (Vancouver) Yang et al, 2004 (Vanco Yang et al, 2004 (Vancouver) Henderson et al, 2011 (Southeast BC)

Yang et al, 2004 (Vancouver) Lin et al, 2005 (Toronto) Luginaah et al, 2005 (Windsor) Lin et al, 2005 (Toronto) Luginaah et al, 2005 (Windsor) Dales et al, 2006 ( 11 cities) Luginaah et al, 2005 (Windsor)

$$
\begin{array}{lllllllllll}
0 & 2 & 4 & 6 & 8 & 10 & 12 & 14 & 16 & 18 \\
& \text { Age (Years) }
\end{array}
$$

Figure 3) Respiratory health outcomes according to air pollutant and children's age range. The age groups of children tested by each reference were plotted for each air pollutant measure tested. Bars indicate either a statistically significant $(P<0.05$, black) or nonsignificant $(P>0.05$, grey $)$ association between the indicated pollutant and the health effect, for each age group studied by the indicated study. A The incidence of emergency department (ED) visits and hospitalizations for asthmatic symptoms and pollution exposure. *Effect was present or stronger in populations with low socioeconomic status. \#ED visits and hospitalizations for bronchiolitis were also included as relevant health outcomes in the study. B Associations between pollution exposure and health services use for conditions other than asthma. C Lung function measurements and symptoms of affected lung function (eg, wheezing and other asthma-like symptoms) were tested for associations with differing levels of pollutant exposure. *Lung function was measured; ${ }^{+}$Lung inflammation was measured; ${ }^{*}$ Asthmatic symptoms were measured. AQHI Air Quality Health Index; CO Carbon monoxide; $\mathrm{NO}_{2}$ Nitrogen dioxide; $\mathrm{O}_{3}$ Ozone; PAHs Polycyclic aromatic hydrocarbons; PM $2.5 / P M_{10}$ Particulate matter size $\leq 2.5 \mu \mathrm{m} / \leq 10 \mu \mathrm{m}$ in aerodynamic diameter; $\mathrm{SO}_{2}$ Sulphur dioxide; TRS Total reduced sulphur; TSP Total suspended particles

government agencies), and the development of epidemiology, spatial and statistical methods applicable to air pollution research (49).

Conversely, similarities across time included the preference for reporting asthma-related outcomes and the use of CAP concentrations as the metric to assess outdoor air pollution exposure. These similarities can be explained by the persistent high prevalence of asthma in Canadian children (50), the availability of high-quality administrative health data, especially for acute asthma-related conditions (51) and detailed CAP data from the air quality monitoring surveillance systems in many densely populated Canadian cities (52).
National air pollution surveillance data have shown that the concentration of CAP gases decreased slightly over time in Canada (53), and mean Canadian CAP levels are lower than those in most of the major cities of the world (54-58). Even at current Canadian levels, however, they are associated with adverse health effects in children, as well as cardiovascular, respiratory and gastrointestinal effects in adults (mainly linked to $\mathrm{SO}_{2}$ and PM) $(59,60)$. Moreover, several of the studies referenced herein suggest heterogeneous effects of the current levels of gases and particles on children according to sex, socioeconomic status and seasonality; however, none of them included an analysis of 
TABLE 2

Characteristics and results of included studies with respiratory symptoms, lung function measures and incidence of asthma diagnosis outcomes

\begin{tabular}{|c|c|c|c|c|c|}
\hline $\begin{array}{l}\text { Author (reference), } \\
\text { year; location; } \\
\text { study period }\end{array}$ & $\begin{array}{l}\text { Study design; study } \\
\text { population and size }\end{array}$ & $\begin{array}{l}\text { Pollutants (mean or median } \\
\text { levels*) and methods } \\
\text { assessing exposure }\end{array}$ & $\begin{array}{l}\text { Respiratory } \\
\text { outcome }\end{array}$ & Study findings & $\begin{array}{c}\text { Adjustment for } \\
\text { confounding factors }\end{array}$ \\
\hline $\begin{array}{l}\text { Pouliou et al (38), } \\
\text { 2008; Hamilton } \\
\text { (Ontario); } \\
\text { 1978-1985 }\end{array}$ & $\begin{array}{l}\text { Reanalysis of cohort } \\
\text { study; } 9-12 \text { year olds } \\
\text { identified by postal } \\
\text { code }(n=1164)\end{array}$ & $\begin{array}{l}\text { TSP measured at } 28 \\
\text { monitoring stations; } \\
\text { exposures assigned to postal } \\
\text { code using Kriging and LUR; } \\
\text { mean of five stations } \\
\text { (station/Kriging/LUR): } \\
58.64 / 55.69 / 58.57\end{array}$ & $\begin{array}{l}\mathrm{FEV}_{1}, \mathrm{FVC} \\
\mathrm{MEF}, \mathrm{PF} \\
\text { survey used } \\
\text { for respiratory } \\
\text { symptoms }\end{array}$ & $\begin{array}{l}\text { OR for association between TSP and } \\
\text { wheezy: } 1.01 \text { (95\% } \mathrm{Cl} 0.99-1.02) \text {, } \\
\text { Cold usually goes to chest: } 1.01 \\
\text { (95\% } \mathrm{Cl} 1.005-1.019) \text {, and having } \\
\text { a cough: } 1.56 \text { (95\% } \mathrm{Cl} 1.35-1.80) \text {; } \\
\text { coefficient for lung measures: FEV } \\
(0.002), \mathrm{FVC}(0.003), \mathrm{MEF}_{75 \%} \\
(0.002) \text {, and } \mathrm{FEF}_{25-75 \%}(0.099) \\
\text { LUR performed better than Kriging }\end{array}$ & $\begin{array}{l}\text { Height, sex, previous } \\
\text { hospitalizations, medical } \\
\text { history of siblings, SES, } \\
\text { parental smoking, use } \\
\text { of gas for cooking } \\
\text { and heating }\end{array}$ \\
\hline $\begin{array}{l}\text { Dales et al (27), } \\
\text { 2008; Windsor } \\
\text { (Ontario); } \\
\text { study period } \\
\text { not stated }\end{array}$ & $\begin{array}{l}\text { Cross-sectional; } \\
\text { 9-12-year-old school } \\
\text { children }(n=2328)\end{array}$ & $\begin{array}{l}\text { Roadway density and } \\
\text { mean/median annual } \\
\mathrm{SO}_{2}(5.39 / 5.28), \mathrm{NO}_{2} \\
(13.58 / 13.15), \mathrm{PM}_{10-2.5} \\
(7.25 / 7.27), \mathrm{PM}_{2.5}\end{array}$ & $\begin{array}{l}\text { FVC, } \text { FEV }_{1}, \\
\text { eNO }\end{array}$ & $\begin{array}{l}3.9 \% \text { eNO increase associated with } \\
1 \mu \mathrm{g} / \mathrm{m}^{3} \text { increase in } \mathrm{PM}_{2.5} \text {; each } \\
\mathrm{km} \text { of road within } 200 \mathrm{~m} \text { associated } \\
\text { with } 6.8 \% \text { increase in eNO, and } \\
0.70 \% \text { decrease in FVC }\end{array}$ & $\begin{array}{l}\text { Previous respiratory } \\
\text { infection, asthma } \\
\text { medication usage, } \\
\text { cigarette exposure and } \\
\text { house pets }\end{array}$ \\
\hline
\end{tabular}

Chen et al (22), Longitudinal study 2008; Vancouver for symptoms and (British Columbia); lung function study period not reported measures; 9-18-yearold asthmatic children $(n=73)$ (15.62/15.42), and black smoke $\left(0.75 / 0.7510^{-5} / \mathrm{m}\right)$; LUR model assigned exposures at postal code level

$\mathrm{NO}_{2}$ concentrations; LUR model assigned exposures for the entire study area at a resolution of $10 \mathrm{~m}$.

$\begin{array}{ll}\text { Dales et al (26), } & \text { Cross-sectional; } \\ \text { 2009; Windsor } & 6-14-y e a r-o l d \\ \text { (Ontario); } & \text { school children } \\ \text { September 2004 } & (n=12,693)\end{array}$

(Ontario);

\author{
Exposure to roadways; \\ total length of local \\ roadways within $200 \mathrm{~m}$ \\ radius around postal code \\ of each house
}

\section{Daily PEF \\ measurements and asthma symptoms reported by parents and measured \\ Respiratory symptoms and illness)} children (diary). Baseline inflammatory markers illnesses (cough, wheezing, chest $\begin{array}{ll}\text { Dales et al (24), } & \text { Cross-sectional; } \\ \text { 2009; Windsor } & 9-14 \text {-year-old } \\ \text { (Ontario); October } & \text { asthmatic school } \\ \text { to December 2005 } & \text { children }(n=182)\end{array}$

Sahsuvaroglu et al Cross-sectional; (39), 2009; 6-7 and 13-14-yearHamilton (Ontario); old school children 1994-1995 $\quad(n=1467)$

\author{
Mean $\mathrm{PM}_{2.5}$ (7.8), $\mathrm{NO}_{2}$ (19.1), Acute (daily) \\ $\mathrm{O}_{3}(14.1), \mathrm{O}_{3 \max }(27.3)$, and $\mathrm{FEV}_{1}$ \\ $\mathrm{SO}_{2}(6.0)$; \\ from monitoring stations
}

\section{Asthma symptoms}

Air pollution in 4 ways: distance from interpolated surfaces of $\mathrm{O}_{3}$ (20.12), $\mathrm{SO}_{2}$ (5.81), $\mathrm{PM}_{10}$ (20.90), $\mathrm{NO}_{X}$ (31.77) from monitoring stations; Krigged $\mathrm{NO}_{2}$ (15.36) surface based on a network of 100 monitors; and LUR for $\mathrm{NO}_{2}$ (14.84) derived from the same monitoring network
Chronic exposure to traffic and psychosocial stress interact to predict both biological and clinical outcomes in children with asthma. The effect of psychosocial stress was more evident among children living in lower-pollution areas.

OR comparing the highest to the lowest exposure (roadway density) quintiles significant for wheeze: 1.23 (95\% Cl 1.07-1.41) and wheeze with dyspnea: OR $1.27(95 \% \mathrm{Cl}$ 1.05-1.52), but not cough, chest illness or asthma; general OR lowest versus others quintiles was 1.08 (95\% Cl 1.012-1.149)

IQR increase $\left(6.0 \mu \mathrm{g} / \mathrm{mm}^{3}\right)$ in the previous $24 \mathrm{~h}$ mean $\mathrm{PM}_{2.5}$ associated with a $0.54 \%(95 \% \mathrm{Cl}$ 0.06-1.02) decrease in bedtime $\mathrm{FEV}_{1}$

Effects were observed for the association of asthma without hay fever and $\mathrm{NO}_{2}$ LUR in 6-7 and 13-14-year-old girls (OR 1.86 [95\% Cl 1.59-2.16]) and 13-14-year-old girls (OR 2.98 [95\% Cl 0.98-9.06]); refined exposure models produced the most robust associations

\author{
Asthma severity, \\ asthma medication use, \\ and demographic \\ characteristics (age, sex, \\ ethnicity, time of year of \\ study visit).
}

Age, sex, parental history of asthma and allergy, parental education, household income, home smokers, number of bedrooms, siblings, pets, stove type, visible indoor moulds

Daily mean temperature, relative humidity, day of the week, number of hours spent on outdoor activities, sex, and study period

Income, dwelling value (Census), smoking data available,

$\%$ houses built pre-1946, rate of repair of housing to account for mould and damp conditions (from Census 1996), Deprivation Index by using principal components analysis for income, education and employment variables 
TABLE 2 - CONTINUED

Characteristics and results of included studies with respiratory symptoms, lung function measures and incidence of asthma diagnosis outcomes

\begin{tabular}{|c|c|c|}
\hline $\begin{array}{l}\text { Author (reference), } \\
\text { year; location; } \\
\text { study period }\end{array}$ & $\begin{array}{l}\text { Study design, study } \\
\text { population and size }\end{array}$ & $\begin{array}{l}\text { Pollutants (mean or median } \\
\text { levels*) and methods } \\
\text { assessing exposure }\end{array}$ \\
\hline $\begin{array}{l}\text { Liu et al (36), 2009; } \\
\text { Windsor (Ontario); } \\
4 \text { weeks: October } \\
\text { to December } 2005\end{array}$ & $\begin{array}{l}\text { Longitudinal repeated } \\
\text { measures study; } \\
\text { 9-14-year-old } \\
\text { asthmatic children } \\
(n=182)\end{array}$ & $\begin{array}{l}\text { 1-day/2-day/3-day median } \\
\mathrm{SO}_{2}(4.5 / 5.0 / 5.6), \mathrm{NO}_{2} \\
(19.8 / 18.3 / 18.3), \mathrm{O}_{3} \\
(13.0 / 14.1 / 14.0) \text {, and } \\
\mathrm{PM}_{2.5}(6.5 / 6.6 / 6.9) ; \text { from } \\
\text { two fixed monitors in study } \\
\text { area }\end{array}$ \\
\hline $\begin{array}{l}\text { Clark et al (23), } \\
\text { 2010; British } \\
\text { Columbia } \\
\text { Southwest; } \\
\text { 1999-2003 }\end{array}$ & $\begin{array}{l}\text { Case-control } \\
\text { population-based } \\
\text { study; children born in } \\
1999 \text { and } 2000 \text { in the } \\
\text { study location; } \\
(n=3482)\end{array}$ & $\begin{array}{l}\text { IDW/LUR modelled } \\
\text { exposures for } \mathrm{NO}, \mathrm{NO}_{2} \text {, } \\
\mathrm{CO}, \mathrm{O}_{3}, \mathrm{PM}_{10}, \mathrm{PM}_{2.5}, \\
\text { black carbon, } \mathrm{SO}_{2} \text {, and } \\
\text { road proximity In utero and } \\
\text { in first year of life based } \\
\text { on monitor data } \\
\text { (see source data) }\end{array}$ \\
\hline
\end{tabular}

Cakmak et al (21), Cross-sectional; Annual volume of vehicles 2012; Windsor 9-11-year-old school within $200 \mathrm{~m}$ radius of (Ontario); February children; $(n=2328) \quad$ child's neighbourhood; to June (year NS) used sensors to measure traffic counts and turning movements
Deger et al (28), Cross-sectional; 2012; Montreal 6 month to 12 year (Quebec); April to olds exposed to July 2006 refinery emissions $(n=482)$
Johnson et al (31), Longitudinal repeated 2013; Windsor

(Ontario); 2004-2005 measures study; asthmatic 10-13 year olds; $(n=45)$

Dell et al (29), 2014; Cross-sectional; Toronto (Ontario); School children June to September grades 1-2 (5-9 2006 year olds); $(n=1497)$

Yearly mean ambient $\mathrm{SO}_{2} \quad$ Symptoms of exposures in children (with active asthma/no active asthma/poor asthma control/ active asthma with acceptable control/no asthma/ controlled asthma) (1.68/1.55/1.90/1.61/1.56); $\mathrm{SO}_{2}$ exposure levels estimated using AERMOD dispersion model

Daily outdoor house levels of $\mathrm{NO}_{2}$ and $\mathrm{PM}_{2.5}$;

Comparison of home monitoring data and LUR temporally refined models based on monitoring site data

Cumulative $\mathrm{NO}_{2}$ exposures; estimations using LUR and IDW models including lifetime addresses (birth, moving, daycare/school and current addresses)

and poor

Current and and wheeze

Respiratory Adjustment for outcome Study findings confounding factors

Pulmonary func- IQR increases in 3-day average $\mathrm{SO}_{2}$, Testing period, interactions tion, airway $\quad \mathrm{NO}_{2}$, and $\mathrm{PM}_{2.5}$ were associated oxidative stress with decreases in forced expiratory and inflammation flow with changes between $-2.8 \%$ of pollutant concentrain asthmatic and $3.1 \% . \mathrm{SO}_{2}, \mathrm{NO}_{2}$ and $\mathrm{PM}_{2.5}$ children were associated with increases in TBARS but not FeNO, 8-isoprostane or interleukin 6; $\mathrm{O}_{3}$ was not associated with health outcomes

Asthma diagnosis Highest OR for asthma diagnosis (incidence) was associated with increased early life exposures to CO $\left(100 \mu \mathrm{g} / \mathrm{m}^{3}\right.$ increase OR 1.10; 95\% Cl 1.06-1.13), NO $\left(10 \mu \mathrm{g} / \mathrm{m}^{3}\right.$ increase OR 1.08 ; tions with sex and use of inhaled corticosteroids $95 \% \mathrm{Cl} 1.04-1.12)$ and $\mathrm{NO}_{2}\left(10 \mu \mathrm{g} / \mathrm{m}^{3}\right.$ increase OR 1.12; 95\% Cl 1.07-1.17); $\mathrm{PM}_{10}, \mathrm{SO}_{2}$, black carbon and proximity roads and pollution point sources also showed significant associations with asthma diagnosis

Respiratory symptoms; FCV, FEV 1 , and eNO

\section{active asthma}

asthma control

OR associated with IQ increase of turning movements: chest congestion 1.20 (95\% Cl 1.06-1.35), FEV decline $1.84 \%$ (95\% Cl 0.007-3.61) OR associated with IQ increase in traffic counts: FVC decrease $0.68 \%$ (95\% Cl 1.32-0.03); effects on asthmatic children were larger; traffic measures had association with effect on eNO

Adjusted PR for IQR increase of $\mathrm{SO}_{2}$ exposure on increased: active asthma: 1.14 (95\% Cl 0.94-1.39); poorly controlled asthma: 1.39 (95\% Cl 1.00-1.94)

$\mathrm{FEV}_{1}$ and PEF

Daily home $\mathrm{NO}_{2}$ associated with $7 \%-8 \%$ decrement in $\mathrm{FEV}_{1} / \mathrm{IQR}$; LUR temporally adjusted models better predicts spatial and temporal variability in lung function models in asthmatic children In children with other allergic disease, lifetime asthma birth, cumulative and $2006 \mathrm{NO}_{2}$ were associated with lifetime asthma and wheeze; no or weaker effects were seen without other allergic diseases
Age, sex, birth weight, gestational age, maternal smoking, maternal age, \# siblings, intention to breast-feed, First Nation status, income quintiles and maternal education quartiles by dissemination area to approximate SES

Ethnic background

(Caucasian versus other), smokers at home, pets at home, acute respiratory illness in past 2 weeks, medication for wheezing/asthma in last 2 weeks, month or the year

Age, sex, parental history of asthma or rhinitis or eczema, household income, maternal educational level, house tobacco smoke; for $\mathrm{SO}_{2}$ models longitude, latitude, emission temperature, height and exit velocity for each vent and stack used

Environmental tobacco smoke, height and weight; home: temperature and relative humidity

Presence of other allergic diseases was tested for effect modification; other variables include ETS and other household exposures, family history of asthma and demographics. 
TABLE 2 - CONTINUED

Characteristics and results of included studies with respiratory symptoms, lung function measures and incidence of asthma diagnosis outcomes

\begin{tabular}{|c|c|c|c|c|c|}
\hline $\begin{array}{l}\text { Author (reference); } \\
\text { year, location; } \\
\text { study period }\end{array}$ & $\begin{array}{l}\text { Study design, study } \\
\text { population and size }\end{array}$ & $\begin{array}{l}\text { Pollutants (mean or median } \\
\text { levels*) and methods } \\
\text { assessing exposure }\end{array}$ & $\begin{array}{l}\text { Respiratory } \\
\text { outcome }\end{array}$ & Study findings & $\begin{array}{l}\text { Adjustment for } \\
\text { confounding factors }\end{array}$ \\
\hline $\begin{array}{l}\text { Smargiassi et al } \\
\text { (40), 2014; } \\
\text { Montreal } \\
\text { (Quebec); } 10 \text { days } \\
\text { between 2009- } \\
2010\end{array}$ & $\begin{array}{l}\text { Longitudinal repeated } \\
\text { measures; asthmatic } \\
\text { 8-12 year olds living } \\
\text { near two oil refineries; } \\
(n=72)\end{array}$ & $\begin{array}{l}\text { Daily personal monitoring of } \\
\mathrm{SO}_{2}, \mathrm{NO}_{2}, \mathrm{PAHs}, \mathrm{VOCs} \\
\text { and } \mathrm{PM}_{2.5} \text { concentrations } \\
\text { (data not shown); passive } \\
\text { samplers for gases and real } \\
\text { time monitor for } \mathrm{PM}_{2.5}(\mathrm{NS})\end{array}$ & $\begin{array}{l}\text { FVC, } \text { FEV }_{1} \text { and } \\
\text { FEF }_{25-75 \%}\end{array}$ & $\begin{array}{l}\text { No consistent associations were } \\
\text { observed with } \mathrm{PM}_{2.5}, \mathrm{NO}_{2} \text { and } \\
\text { benzene; suggestion of small } \\
\text { decrease in respiratory function } \\
\text { with PAHs (FVC: }-9.9 \mathrm{~mL} \text { per IQR } \\
\text { PAH [95\% Cl }-23.4 \text { to } 3.7] \text { ) }\end{array}$ & $\begin{array}{l}\text { Within-subject serial corre- } \\
\text { lation, medication use, } \\
\text { parent's or caregiver's } \\
\text { education, ethnicity, } \\
\text { temperature, relative } \\
\text { humidity, age, height, } \\
\text { sex, and the design } \\
\text { variable month of study }\end{array}$ \\
\hline
\end{tabular}

*Parts per billion for gasses, $\mu \mathrm{g} / \mathrm{m}^{3}$ for particulate matter (PM) and total suspended particles (TSP). CO Carbon monoxide; ED Emergency department; eNO Exhaled nitric oxide; ETS Environmental tobacco smoke; FEF $25-75 \%$ Forced expiratory flow between $25 \%$ and $75 \%$ of the forced vital capacity (FVC); FeNO Fractional exhaled nitric oxide; FEV 1 Forced expiratory volume in $1 \mathrm{~s}$; IDW Inverse distance weighted; IQ Interquartile; IQR IQ range; LUR Land use regression; MEF $75 \%$,

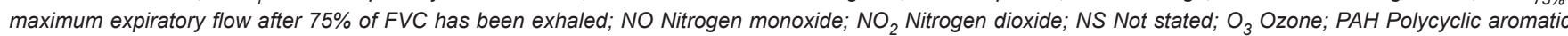
hydrocarbon; PEF Peak expiratory flow; PF Pulmonary function; PR Prevalence ratio; RR Relative risk; SES Socioeconomic status; SO 2 Sulphur dioxide; TBARS Thiobarbituric acid reactive substances; VOC Volatile organic compound

potential mechanisms explaining those differences, which may vary across populations (61).

\section{Limitations}

The methodological quality of the studies included in the present review was relatively homogeneous, with a mean 'moderate quality' score according to the NOS tool. This 'moderate' score is lower than expected for most included articles because the NOS tool is designed only for classic cohort or case-control studies. Thus, we believe that properly assessing the quality of observational studies related to environmental health remains challenging.

To avoid selection bias in the present review, two independent reviewers conducted the screening and selection processes. Although efforts to undertake meta-analyses failed due to the high qualitative heterogeneity in the included studies, qualitative summary tables and graphs were developed to examine trends. Having more homogeneous studies in terms of children's age in studies would allow quantitative analysis in future reviews. Another limitation of the review was that unpublished studies in the formal scientific literature were not identified; therefore, there may be a chance of publication bias. However, the included studies showed both positive and null effects of different CAP for different cities. In fact, the common mixture of positive and null effects in many studies may be explained by the fact that air pollutants effects differ not only according to type of pollutant (alone or in combination), but also by the different physical and sociodemographic conditions of the places and populations under study. Finally, the scope of the present review was limited to the childhood population and the results and conclusions may be not generalizable to adults, even in Canada.

\section{CONCLUSIONS}

The present review provides researchers, clinicians and environmental health authorities with a current summary of the evidence linking the adverse effects of outdoor air pollution to children's respiratory health in Canada. Further studies should fill knowledge and methodological gaps that are related but not restricted to: deepening the understanding of the 'why' of the differences in the observed adverse effects for some pollutants and socioeconomic conditions across cities; exploring the combined effect of various air pollutants; expanding the study of the health effects of nonCAP air toxicants that are emitted in Canada, such as PAH or volatile organic compounds; strengthening the advances in epidemiological, spatial, statistical and social analysis as applied to air pollution studies, aiming for a more integrated approach between the physical and social environment; and developing and validating a tool for assessing the methodological quality of observational studies commonly used in environmental health studies, other than cohort and case control studies.
ACKNOWLEDGEMENTS: The authors thank Mrs Maria Tan, library consultant at the John W Scott Health Sciences Library at University of Alberta for her support in defining the specific search strings. Author contributions: LR-V designed the study, undertook the literature searches, study assessment, data extraction and analysis. AM conducted study assessment, data extraction and analysis. AO-V contributed as third reviewer in the selection process and contributed to the data interpretation. BR contributed to the study design and data interpretation. All authors contributeed to writing and editing the manuscript, and approved the final version for publication.

FUNDING: The study was supported by the Emergency Medicine Research Group (EMeRG) affiliated with the Department of Emergency Medicine, and by the Department of Pediatrics, University of Alberta. Dr Rodriguez-Villamizar is supported by COLCIENCIAS Colombia. Adam Magico's postdoctoral research is supported by a Hair Massacure grant to Dr Osornio-Vargas. Dr Rowe's research is supported by a Canadian Institutes of Health Research through a Tier I Canada Research Chair in Evidence-based Emergency Medicine from the Government of Canada (Ottawa, Ontario) 


\section{APPENDIX 1}

\section{OVID MEDLINE, CINAHL Plus, Scopus and CAB search} strategies

\section{Ovid MEDLINE sequence and terms}

1. Air Pollution/

2. air pollutants/ or gasoline/ or hydrogen sulfide/ or particulate matter/ or sulfur dioxide/ or vehicle emissions/

3. ("Air pollution" or "air pollutant").mp. [mp=title, abstract, original title, name of substance word, subject heading word, keyword heading word, protocol supplementary concept word, rare disease supplementary concept word, unique identifier]

4. ("ambient air pollution" or "outdoor air pollution").mp. [mp=title, abstract, original title, name of substance word, subject heading word, keyword heading word, protocol supplementary concept word, rare disease supplementary concept word, unique identifier]

5. 1 or 2 or 3 or 4

6. asthma/ or bronchitis/ or respiration disorders/

7. ("respiratory health" or "asthma" or "respiratory condition*”).mp. [mp=title, abstract, original title, name of substance word, subject heading word, keyword heading word, protocol supplementary concept word, rare disease supplementary concept word, unique identifier]

8. ("respiratory symptoms" or "wheeze" or "respiratory function" or "pulmonary function").mp. [mp=title, abstract, original title, name of substance word, subject heading word, keyword heading word, protocol supplementary concept word, rare disease supplementary concept word, unique identifier]

9. 6 or 7 or 8

10. Child/

11. (“child"” or "adolesc" or "teen*” or "youth" or "pediat").mp. [mp=title, abstract, original title, name of substance word, subject heading word, keyword heading word, protocol supplementary concept word, rare disease supplementary concept word, unique identifier]

\section{10 or 11}

13. canada/ or alberta/ or british columbia/ or manitoba/ or new brunswick/ or "newfoundland and labrador"/ or northwest territories/ or nova scotia/ or nunavut/ or ontario/ or prince edward island/ or quebec/ or saskatchewan/ or yukon territory/

14. ("Canada" or "Vancouver" or "Edmonton" or "Calgary" or "Victoria" or "Regina" or "Saskatchewan" or "Winnipeg" or "Toronto" or "Hamilton" or "Windsor" or "Mississauga" or "Montreal" or "Halifax" or "Ottawa" or "Kingston" or "London").mp. [mp=title, abstract, original title, name of substance word, subject heading word, keyword heading word, protocol supplementary concept word, rare disease supplementary concept word, unique identifier]

15. 13 or 14

16. 5 and 9 and 12 and 15

17. limit 16 to $y r=" 2004$-Current"

CINAHL Plus sequence and string terms*

1. Air pollut*

2. (Respirat* OR Asthm* OR Pulmon*)

3. 1 and 2

4. (Child* OR adolescen*)

5. 3 and 4

Scopus exact string terms

TITLE-ABSKEY

(AIR POLLUT* AND (RESPIRAT* OR ASTHM* OR PULMON*) AND (CHILD* OR ADOLESCEN*) AND CANAD*)

AND SUBJAREA

(MULT OR AGRI OR BIOC OR IMMU OR NEUR OR PHAR OR MULT ORMEDI OR NURS OR VETE OR DENT OR HEAL)

AND PUBYEAR > 2003

\section{CAB abstracts}

("air pollut*” AND "respirat*" AND "child"” AND "Canada").

Indexes=CAB Abstracts Timespan=2004-2014

*Limiters - Published Date: 20040101-20140231; Geographic Subset: Canada; Age Groups: All Child

\section{REFERENCES}

1. Brunekreef B, Holgate ST. Air pollution and health. Lancet 2002;360:1233-42.

2. (WHO) WHO. Air pollution 2013 <www.who.int/topics/air_ pollution/en/> (Accessed April 5, 2013).

3. Van Donkelaar A, Martin R V, Brauer M, et al. Global estimates of ambient fine particulate matter concentrations from satellite-based aerosol optical depth: Development and application. Environ Health Perspect 2010;118:847-55.

4. Nemmar A, Holme J a, Rosas I, Schwarze PE, Alfaro-Moreno E. Recent advances in particulate matter and nanoparticle toxicology: A review of the in vivo and in vitro studies. Biomed Res Int 2013;2013:279371.

5. International Agency for Research on Cancer. Outdoor air pollution a leading environmental cause of cancer deaths. 2013. Press Release No. 221. <www.iarc.fr/en/media-centre/ iarcnews/pdf/pr221_E.pdf> (Accessed January 17, 2014).

6. Schwartz J. Air pollution and children's health. Pediatrics 2004;113:1037-43

7. Kappos AD, Bruckmann P, Eikmann T, et al. Health effects of particles in ambient air. Int J Hyg Env Heal 2004;207:399-407.

8. Gilliland F, McConnell R, Peters J, Gong H. A theoretical basis for investigating air pollution and children's respiratory health. Environ Health Perspect 1999;107(Suppl 3):403-7.

9. Dixon JK. Kids need clean air: Air pollution and children's health. Fam Community Heal 2002;24:9-26.

10. Holguin F. Traffic, outdoor air pollution, and asthma. Immunol Allergy Clin North Am 2008;28:577-88, viii-ix.

11. Organization for Economic Co-operation and Development. The cost of air pollution: Health impacts of road transport. Paris: OECD Publishing; 2014.

12. World Health Organization. The global burden of disease: 2004 update. World Health Organization, ed. Geneva; 2008.

13. Stieb D, Liu L. Air quality impacts on health. In: Taylor E, McMIllan A, eds. Air Quality Management: Canadian Perspectives on a Global Issue. Dordrecht: Springer; 2014:388.

14. Evans L. Diversity in Canada: an overview. Canadian Immigrant. $2013<$ http://canadianimmigrant.ca/guides/moving-to-canada/ diversity-in-canada-an-overview $>$ (Accessed February 13, 2015).

15. Esposito S, Tenconi R, Lelii M, et al. Possible molecular mechanisms linking air pollution and asthma in children. BMC Pulm Med BMC Pulmon Med 2014;14:31

16. Koranteng S, Osornio-Vargas A, Buka I. Ambient air pollution and children's health: A systematic review of Canadian epidemiological studies. Paediatr Child Health 2007;12:225-33.

17. Wells GA, Shea B, O'Connell D, et al. The Newcastle-Ottawa Scales (NOS) for assessing the quality of nonrandomized studies in meta-analyses. Ottawa: University of Ottawa. <www.ohri.ca/ programs/clinical_epidemiology/oxford.asp > (Accessed March 12, 2014).

18. Higgins JP, Green S, eds. Cochrane Handbook for Systematic Reviews of Interventions Version 5.0.2. [updated September 2009]. The Cochrane Collaboration. 2009. <www.cochrane-handbook. org $>$ (Accessed January 5, 2013).

19. Moher D, Liberati A, Tetzlaff J, Altman DG. Preferred reporting items for systematic reviews and meta-analyses: The PRISMA statement. PLoS Med 2009;6:e1000097.

20. Burra TA, Moineddin R, Agha MM, Glazier RH. Social disadvantage, air pollution, and asthma physician visits in Toronto, Canada. Environ Res 2009;109:567-74.

21. Cakmak S, Mahmud M, Grgicak-Mannion A, Dales RE. The influence of neighborhood traffic density on the respiratory health of elementary schoolchildren. Environ Int 2012;39:128-32.

22. Chen E, Schreier HM, Strunk RC, Brauer M. Chronic trafficrelated air pollution and stress interact to predict biologic and clinical outcomes in asthma. Environ Health Perspect 2008;116:970-5.

23. Clark NA, Demers PA, Karr CJ, et al. Effect of early life exposure to air pollution on development of childhood asthma. Environ Health Perspect 2010;118:284-90.

24. Dales R, Chen L, Frescura AM, Liu L, Villeneuve PJ. Acute effects of outdoor air pollution on forced expiratory volume in $1 \mathrm{~s}$ : A panel study of schoolchildren with asthma. Eur Respir J 2009;34:316-23.

25. Dales RE, Cakmak S, Doiron MS. Gaseous air pollutants and hospitalization for respiratory disease in the neonatal period. Environ Health Perspect 2006;114:1751-4. 
26. Dales R, Wheeler AJ, Mahmud M, Frescura A-M, Liu L. The influence of neighborhood roadways on respiratory symptoms among elementary schoolchildren. J Occup Environ Med 2009;51:654-60.

27. Dales R, Wheeler A, Mahmud M, et al. The influence of living near roadways on spirometry and exhaled nitric oxide in elementary schoolchildren. Environ Health Perspect 2008;116:1423-7.

28. Deger L, Plante C, Jacques L, et al. Exposed to air stack emissions of sulphur dioxide from petroleum refineries in Montreal, Quebec: A cross-sectional study. Can Respir J 2012;19:97-102.

29. Dell SD, Jerrett M, Beckerman B, et al. Presence of other allergic disease modifies the effect of early childhood traffic-related air pollution exposure on asthma prevalence. Environ Int 2014;65:83-92.

30. Henderson SB, Brauer M, Macnab YC, Kennedy SM. Three measures of forest fire smoke exposure and their associations with respiratory and cardiovascular health outcomes in a populationbased cohort. Environ Health Perspect 2011;119:1266-71.

31. Johnson M, Macneill M, Grgicak-Mannion A, et al. Development of temporally refined land-use regression models predicting daily household-level air pollution in a panel study of lung function among asthmatic children. J Expo Sci Environ Epidemiol 2013;23:259-67.

32. Lavigne E, Villeneuve PJ, Cakmak S. Air pollution and emergency department visits for asthma in Windsor, Canada. Can J Public Health 2012;103:4-8.

33. Lewin A, Buteau S, Brand A, Kosatsky T, Smargiassi A. Short-term risk of hospitalization for asthma or bronchiolitis in children living near an aluminum smelter. J Expo Sci Environ Epidemiol 2013;23:474-80

34. Lin M. Gaseous air pollutants and asthma hospitalization of children with low household income in Vancouver, British Columbia, Canada. Am J Epidemiol 2004;159:294-303.

35. Lin M, Stieb DM, Chen Y. Coarse particulate matter and hospitalization for respiratory infections in children younger than 15 years in Toronto: A case-crossover analysis. Pediatrics 2005; 116:e235-40.

36. Liu L, Poon R, Chen L, et al. Acute effects of air pollution on pulmonary function, airway inflammation, and oxidative stress in asthmatic children. Environ Health Perspect 2009;117:668-74.

37. Luginaah IN, Fung KY, Gorey KM, Webster G, Wills C. Association of ambient air pollution with respiratory hospitalization in a government-designated "area of concern": The case of Windsor, Ontario. Environ Health Perspect 2004;113:290-6.

38. Pouliou T, Kanaroglou PS, Elliott SJ, Pengelly LD. Assessing the health impacts of air pollution: A re-analysis of the Hamilton children's cohort data using a spatial analytic approach. Int J Environ Health Res 2008;18:17-35.

39. Sahsuvaroglu T, Jerrett M, Sears MR, et al. Spatial analysis of air pollution and childhood asthma in Hamilton, Canada: Comparing exposure methods in sensitive subgroups. Environ Health 2009;8:14

40. Smargiassi A, Goldberg MS, Wheeler AJ, et al. Associations between personal exposure to air pollutants and lung function tests and cardiovascular indices among children with asthma living near an industrial complex and petroleum refineries. Environ Res 2014;132:38-45.

41. Smargiassi A, Kosatsky T, Hicks J, et al. Risk of asthmatic episodes in children exposed to sulfur dioxide stack emissions from a refinery point source in Montreal, Canada. Environ Health Perspect 2009;117:653-9.

42. Szyszkowics M, Kousha T. Emergency department visits for asthma in relation to the Air Quality Health Index: A case-crossover study in Windsor, Canada. Can J Public Health 2014;105:e336-e341.
43. Szyszkowicz M. Ambient air pollution and daily emergency department visits for asthma in Edmonton, Canada. Int J Occup Med Environ Health 2008;21:25-30.

44. To T, Shen S, Atenafu EG, et al. The air quality health index and asthma morbidity: a population-based study. Environ Health Perspect 2013;121:46-52.

45. Villeneuve PJ, Chen L, Rowe BH, Coates F. Outdoor air pollution and emergency department visits for asthma among children and adults: a case-crossover study in northern Alberta, Canada. Environ Health 2007;6:40.

46. Yang Q, Chen Y, Krewski D, Shi Y, Burnett RT, McGrail KM. Association between particulate air pollution and first hospital admission for childhood respiratory illness in Vancouver, Canada. Arch Environ Health 2004;59:14-21.

47. Environment Canada G. Canadian ambient air quality standards. Canadian Environmental Protection Act. 2013. p. Sections 54-5. $<$ www.ec.gc.ca/default.asp?lang=En\&n=56D4043B$1 \&$ news $=$ A 4B2C28A-2DFB-4BF4-8777-ADF29B4360BD> (Accessed January 21, 2013).

48. Canadian Institutes of Health Research. Human Development, Child and Youth Health strategic research priorities. IHDCYH Strategic Plan 2013-2017: Healthy Foundations of Life. 2011:27. <www.cihr-irsc.gc.ca/e/documents/ihdcyh_strategic_plan_2013 2018-en.pdf> (Accessed January 20, 2014).

49. Duncan T. Statistical Methods in Environmental Epidemiology. New York: Oxford University Press, Inc, 2009.

50. Garner R, Kohen D. Changes in the prevalence of asthma among Canadian children. Health Rep 2008;19:45-50.

51. To T, Dell S, Dick PT, Cicutto L, et al. Case verification of children with asthma in Ontario. Pediatr Allergy Immunol 2006;17:69-76.

52. Environment Canada. Air Quality Monitoring Networks and Data. <www.ec.gc.ca/air-sc-r/default.asp?lang=En\&n=C87142DF-1> (Accessed January 21, 2014).

53. Environment Canada. 10 years of data from the National Air Pollution Surveillance (NAPS) Network, data summary from 1999 to 2008. Ottawa: 2013:213.

54. Braga AL, Saldiva PH, Pereira LA, et al. Health effects of air pollution exposure on children and adolescents in Sao Paulo, Brazil. Pediatr Pulmonol 2001;113:106-13.

55. Romieu I, Meneses F, Ruiz S, et al. Effects of air pollution on the respirtory health of asthmatic children living in Mexico city. J Respir Crit Care Med 1996;154:300-7.

56. Millman A, Tang D, Perera FP. Air pollution threatens the health of children in China. Pediatrics 2008;122:620-8.

57. Baldasano JM, Valera E, Jiménez P. Air quality data from large cities. Sci Total Environ 2003;307:141-65.

58. Gurjar BR, Butler TM, Lawrence MG, Lelieveld J. Evaluation of emissions and air quality in megacities. Atmos Environ 2008;42:1593-606.

59. Jerrett M, Burnett RT, Brook J, et al. Do socioeconomic characteristics modify the short term association between air pollution and mortality? Evidence from a zonal time series in Hamilton, Canada. J Epidemiol Community Health 2004;58:31-40.

60. Villeneuve PJ, Johnson JY, Pasichnyk D, Lowes J, Kirkland S, Rowe BH. Short-term effects of ambient air pollution on stroke: Who is most vulnerable? Sci Total Environ 2012;430:193-201.

61. O'Neill MS, Jerrett M, Kawachi I, et al. Health, wealth, and air pollution: Advancing theory and methods. Environ Health Perspect 2003;111:1861-70. 


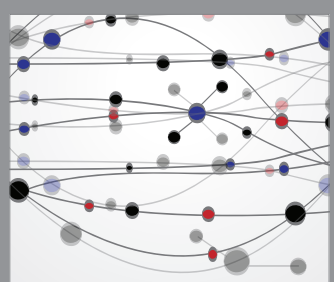

The Scientific World Journal
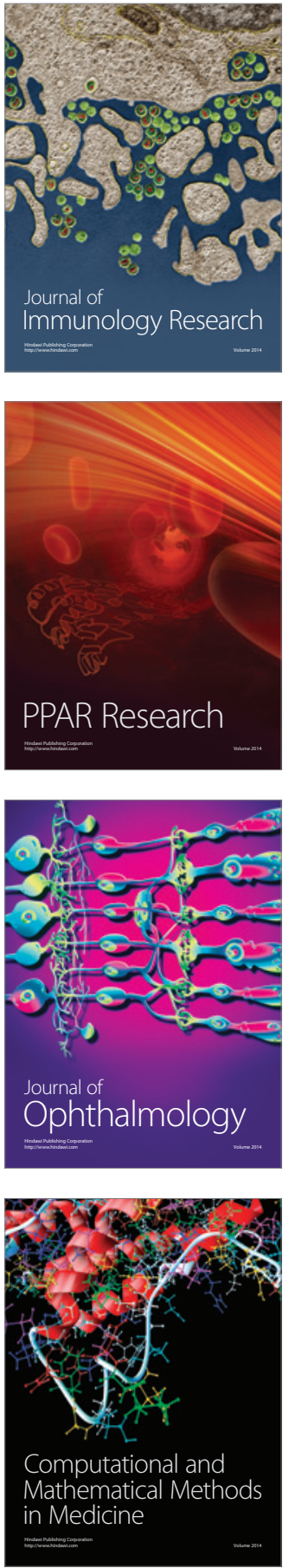

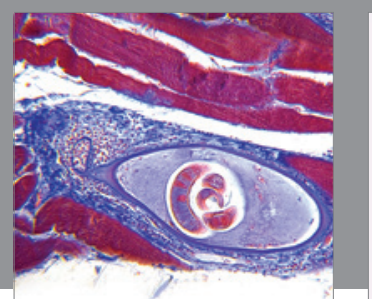

Gastroenterology Research and Practice

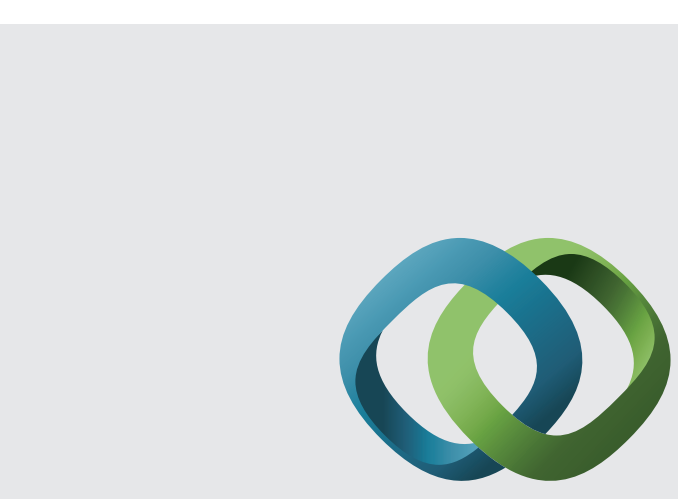

\section{Hindawi}

Submit your manuscripts at

http://www.hindawi.com
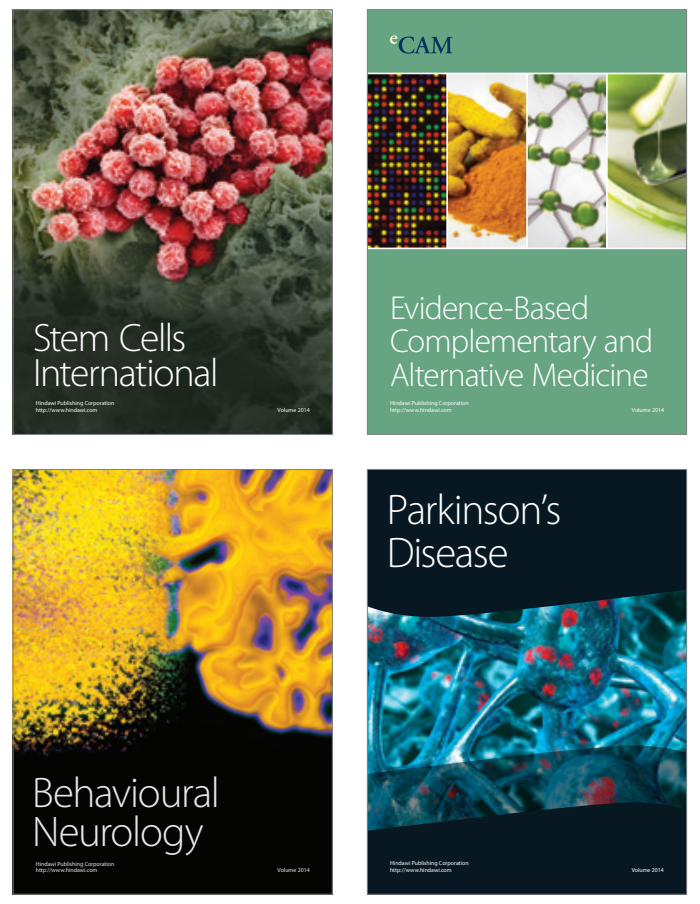
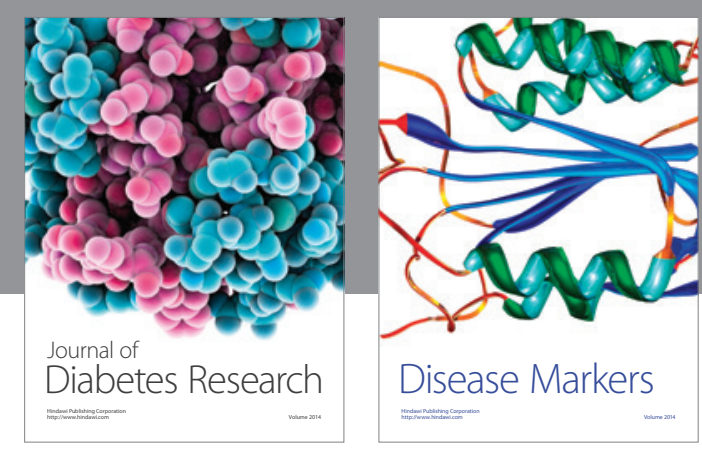

Disease Markers
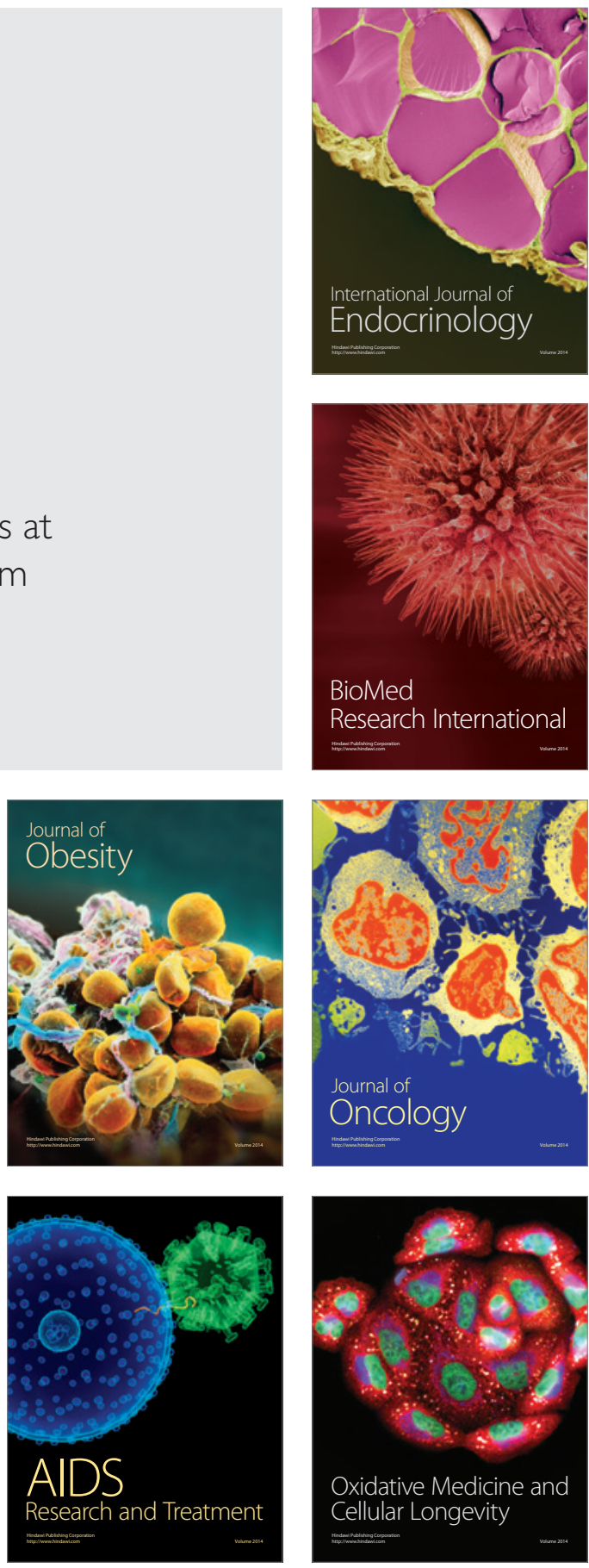